\author{
https://doi.org/10.52449/1857-4114.2020.36-2.06
}

CZU: 159.9+796.012:796.85+355.233

\title{
DEPENDENCE BETWEEN THE LEVEL OF PSYCHOMOTOR CAPACITY DEVELOPMENT AND THE ACQUISITION OF TECHNICAL MARTIAL ARTS PROPERTIES BY MILITARY STUDENTS
}

\author{
Mihalache Gheorghe ${ }^{1}$ \\ Jurat Valeriu', ORCID: 0000-0003-0466-3242 \\ Enăchescu Valentin-Sorin ${ }^{3}$ \\ ${ }^{1}$ Air Force Academy "Henri Coanda", Brasov, Romania \\ ${ }^{2}$ State University of Physical Education and Sport, Chisinau, Republic of Moldova \\ 3 "Ferdinand I" Military Technical Academy, Bucharest, Romania
}

\begin{abstract}
Numerous scientific studies report on the importance of improving the methodology of developing motor skills through martial arts, while identifying the links between these indices, which ensures an optimal level of motor training of subjects. In this paper are presented the results of the study on the existence of correlative links between the indices of motor skills development and the level of mastery of the technique of the martial arts elements. For this purpose, a test was carried out in which the military students (first year) of the "Henri Coandă" Air Force Academy from Brasov participated. The test results confirmed the existence of a reciprocal link, highlighting significant interdependencies between the indices obtained. The analysis of the correlation of the parameters of motor skills and the level of mastery of technical elements in martial arts allow us to mention that the intensity of links is significant at high and medium levels in most cases, which reflects the fact that the indices influence each other.
\end{abstract}

Keywords: military students, general physical training, psychomotor skills, technical procedures, martial arts, military physical education.

The actuality and importance of the approached topic. The evolution of society in terms of knowledge requires structural and conceptual changes in each category of concerns. Thus, the inclusion of the armed forces in various international military alliances has led to changes in strategic concepts of action, additions to military technology, and an adaptation of specialist training to the new conditions.

The training of military specialists must be at the level of the alliance countries to which it belongs. Thus, in the last 30 years the military education system has been subjected to a dynamic process of adaptation, completion and reconsideration of the content of the study disciplines, starting from the admission / recruitment system, to the graduation one. Several regulations $[9,10,11]$ make references to the content of physical training, with strict reference to the content elements regarding the individual capacity for self-defense. Self-defense, by using the techniques of judo, karate-do and hand-to-hand combat, with the individual weapons provided, is a basic objective of military physical training $[1,2,4,6]$. In order to achieve this objective, legislative decisions were established, which were included in the general military training regulations.

The process of military training and instruction aims at mastering by military students the principles of using small subunits (team, group and information platoon) in 
military actions, training leadership and instructor skills, and skills needed to train for the first military position.

General military training is performed in an integrated functional system, following individual and collective training through: military training and instructional courses / sessions and road legislation courses / sessions; practical military training activities carried out in convocations / training camps, practical military physical education activities and practical driving activities [8].

Given the complexity of the profession of officer and leader at the same time, with subordinates in the not too distant future, with participation in missions in different theaters of operations, as subordinates or leaders, physical training must be central, with a complex baggage of theoretical knowledge, but in the conditions in which we do not turn them into theorists $[3,5,7]$.

From this perspective, military training, based on self-defense techniques, suggests that martial arts are directly applicable to describe and formulate the ongoing training system, which aims to achieve and maintain ongoing training to combat various threats.

Preparations for military self-defense should include exercises aimed at improving psychomotor self-control, which is essential for effective performance in extremely difficult and stressful conditions associated with the threat of physical aggression.

For these reasons, the scientific problem of research is the selection and use of a number of martial arts-specific means in the process of developing psychomotor skills (general and special physical training) for military students in lessons on "self-defense" and some topics in military physical education, such as the methodological substantiation of their application. Also, it was intervened on the thematic planning for the discipline "Military Physical Education" by merging the hours assigned to the course "Self-Defense" for the three years of study in a single academic year.
The aim of the paper is to determine the influence of martial arts means (aikido, judo, karate) applied in the conduct of military physical education lessons on the development of psychomotor qualities of future officers.

\section{Research objectives:}

- the study of the literature of the specialized field regarding the methodology of development and improvement of the psychomotor abilities of the military students by specific means from the arts martial arts (aikido, judo, karate);

- determining the level of general and special physical training, the level of handling the technique of martial arts elements of military students in the military physical education system;

- highlighting the correlation between the indications of general and special physical training and the technique of the elements from martial arts in the process of developing the psychomotor abilities of military students.

Research methods and organization. For the good development of the study, the following research methods and evaluation tests were used: analysis of the specialized literature; pedagogical observation; measurement and evaluation techniques; pedagogical experiment; statisticalmathematical method.

The pedagogical experiment took place during the academic year 2017-2018 in military physical education lessons with two groups of first year students (32 students in a group) of the Air Force Academy "Henri Coanda" Brasov, who participated in a total of 84 lessons. In the experiment, initial and final tests were performed on the two groups of subjects to determine the dynamics of the level of general physical training based on the application in the process of military physical education of martial arts means. The performances obtained by the military students were analyzed and subjected to mathematicalstatistical processing in order to highlight the effectiveness of the application of martial arts means and to determine the correlation 
between the sizes of the indices analyzed in the research process.

Research results. Following the statistical analysis of the data obtained from the tests performed on the level of general physical training (Figure 1), good values of the correlation coefficients are observed, these being between $r=-0.33$ (running per $100 \mathrm{~m}$ ) and $\mathrm{r}=0,80$ (lifting the torso from lying face down at the gymnastic box, experimental group). Taking into account the value of the correlation coefficient, it can be seen that the minimum value $(0.30$ - obtained when running per $100 \mathrm{~m}$ ) has a weak correlation and is completely isolated, the others being at least 0.47 .
The largest difference in the correlation coefficient between the two groups was found in the plyo push-ups test (approximately 0,20), where we have a high correlation for the experimental group, a situation that is explained by the fact that it is not just a simple evaluation test of the scapula-humeral shaft force, but also has an element of coordination between the upper and lower limbs, as well as a good development of the back muscles. This additional coordination of the subjects from the experimental group is based on the development of this quality by practicing martial arts techniques.

A rather large difference in the value of the correlation was also found in the tests: "hanging leg raises" and "plyometric jumps".

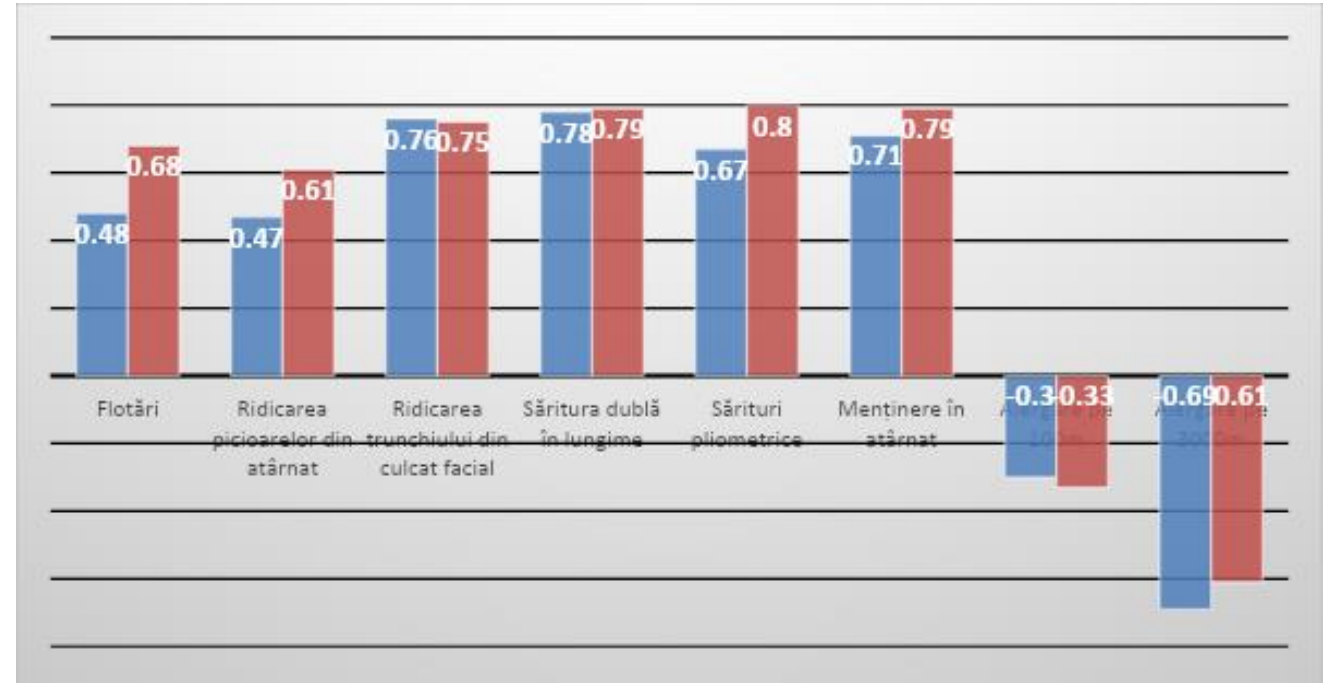

Fig. 1. Correlation of the general physical training indices of the experimental and control groups

In the " hanging leg raises " test, a very high correlation coefficient value was registered, higher than the experimental group, because it requires a force in the forearm muscles as well as a high level of perseverance. Martial arts, especially judo, which require direct holds on your partner's equipment, have a decisive effect on the development of strength in the forearm muscles.

In the tests of " lifting the torso from lying face down " and in the "long jump from squat to squat position", in both groups there was a high correlation between the means of training. This aspect can be attributed to the fact that both training programs contain means that determine the development of the back and thigh muscles and, implicitly, the increase of strength.

The only test in which there was a higher correlation in the control group, but both are correlations at the upper limit (for the experimental group), was recorded in the running test at a distance of $3000 \mathrm{~m}$. At the 
same time, the experimental program, based on the means of martial arts, registered a good correlation, even if it is slightly lower $(0,08)$, because they were performed even in order to develop resistance (they were repeated many times). We believe that the difference is justified by the fact that the repetition of technical procedures in martial arts develops anaerobic resistance due to high tension, blocked chest and period of apnea during execution.

A high correlation was also found in the "continuing hanging after 8 traction" test, because it is a classic test for entrance exams, as well as a periodic test during studies.
However, the experimental group recorded a higher correlation $(0,08)$ for that increased strength in the forearm muscles, which is due to the holds encountered in judo and some aikido procedures.

Correlative analysis of special physical training indices (Figure 2) leads to some comments similar to those regarding the correlation of the tests of general physical training, taking into account that the minimum values are: $r=0,60$, obtained by the subjects of the experimental group in the test "Scândurica" and $\mathrm{r}=0,81$ in the test , Orientation and coordination".

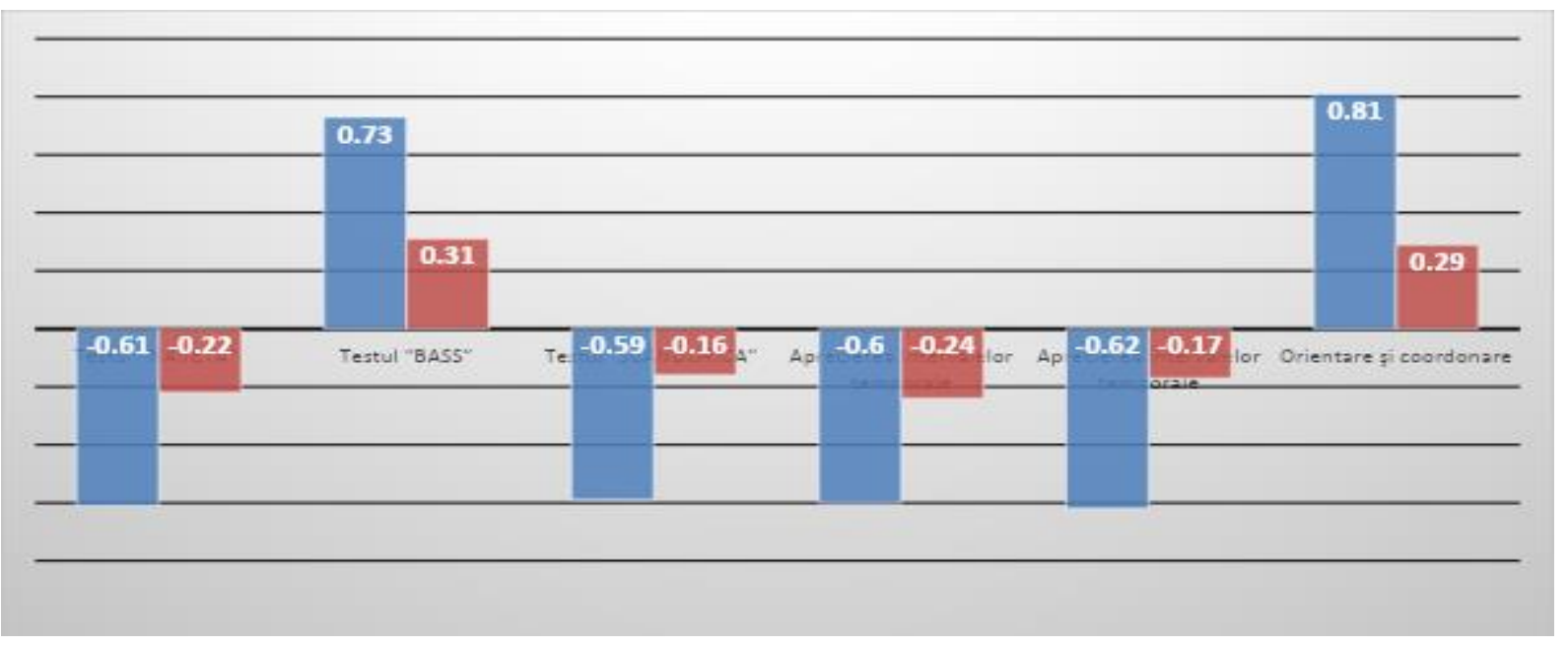

Fig. 2. Correlation of special physical training indices of the experimental and control groups

These values obtained by the subjects of the experimental group frame the correlation coefficient to the high and very high category.

Thus, the test "Orientation and coordination", there was a very high correlation, because, as most authors of scientific literature in the field of martial arts, the complexity of technical procedures determines a development of general coordination and spatio-temporal orientation. Also, the subjects of the experimental group practiced the techniques in different situations (directions, rhythm, stress, etc.) during the two semesters.
In the tests "Shuttle", "Assessment of time intervals of $3 \mathrm{sec}$ " and "Assessment of time intervals of $5 \mathrm{sec",} \mathrm{a} \mathrm{high} \mathrm{correlation} \mathrm{was}$ found, because these tests also contain a side of the speed of movement and reaction.

In the "Scândurica" test, the subjects of the experimental group registered a reasonable correlation at the upper limit. This is explained by the fact that the test requires a special concentration, increased attention, as well as a high observational spirit. These features are also developed through the practice of martial arts, but they are consolidated over a long period of time (after years of practice). 
Compared to the experimental group, the correlation coefficients between $r=0.16$ and $r$ $=0.31$ were registered in the subjects of the control group, namely in the category of very weak and weak correlation. The lowest correlation coefficient was registered in the "Scândurica" test (as well as in the experimental group), due to the particularities presented previously. In the "Orientation and coordination" test, the value of the correlation index is weak, because the subjects performed a selection procedure for all evaluation criteria. In other words, although they were able to opt for a choice procedure, they still failed to get a good result. The appreciation of time intervals ( $3 \mathrm{sec}$ and $5 \mathrm{sec}$ ) registers a nonexistent correlation, respectively very weak, because the classical means of action do not appeal to such requirements (time appreciation), although it represents a special professional aspect for the future military officers.

Therefore, the above statements are fully justified by the comparative analysis of the correlations of good performance obtained by the experimental group to special physical training in the two tests analyzed, initial and final, where we can conclude that the application of martial arts means has a strong impact on the particularities and manifestations, which emphasize the psychic side of the motor abilities specific to the military officer.

Correlative analysis of the indices of mastering the technical procedures. Similar to the results obtained at the indices of general and special physical training, we analyzed the way in which the work programs determined the progress of the indices obtained by the subjects of the experimental group to acquire the technical tests.

When evaluating the technical procedures (Figure 3), a very high correlation was registered, with one exception, when evaluating the Ude Osae technique, where a reasonable correlation was registered. This result is due to the fact that the experimental program included a judicious planning of the means of action on the three working days distributed per week. At the same time, another reason for this evolution is the students' desire to assimilate new movements (unique procedures, combinations) in order to be able to apply them in conditions of adversity, of effective struggle.

Although it contains means of action like all the others, the direct fight with an established opponent represents an expected moment of the lesson, because it represents a superior form to ascertain the level of assimilation of the skills and to establish a value hierarchy within the group.

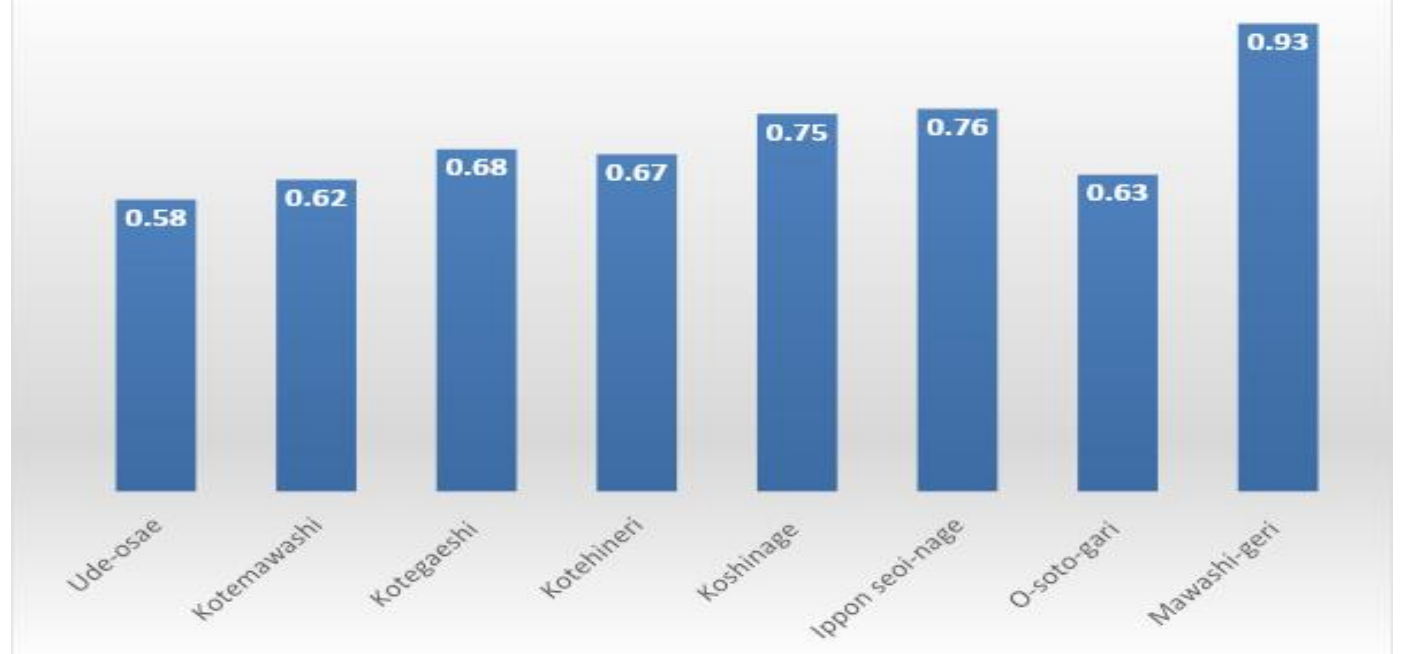

Fig. 3. Correlation of the results of the evaluation of the technical procedures in the experimental group 
The values obtained suggest the existence of the correlation between the analyzed values, these being between $r=0.58$ (Ude Osae) and $r$ $=0.93$ (Mawashi in 10 seconds), thus the hypothesis according to which the progress is due to the work schedule, we consider that it is proven. An additional justification of this statement is the value $r=0,965$ of the correlation coefficient determined at the average values of the performances obtained by the subjects of the experimental group at the technical techniques at the two evaluations.

The correlative analysis of the results of the evaluation of the technical procedures and the indices of general physical training for the experimental group was organized as follows:

a) (Percentage) Progresses were determined for each technical procedure between the two evaluations;

b) The average of these progresses was determined for each procedure;

c) (Percentage) progresses were determined in each general physical training test between the two assessments;

d) The data from point b) were correlated, in turn, with each of those from point c).

The results obtained and presented in Figure 4 demonstrate that there is a correlation between reasonably in push-up test, $100 \mathrm{~m}$ run, $3000 \mathrm{~m}$ run, as well as a high correlation in the other tests (hanging legs raises, hanging trunk raises, long jump from squat to squat position, plyometric jumps and continuing hanging after traction).

The results of tests in which the correlation is reasonable can be motivated by the fact that the speed of movement is more difficult to develop in old age, and the execution of technical procedures favors to a limited extent the development of aerobic endurance. Even if the plyo push ups test is in the category of reasonable correlation (0.54), it is at the upper limit and is explained by the synchronization of the development of two large categories of muscles: the extensor muscles of the scapulo humeral shaft and the back muscles. By performing the technical procedures, the flexor muscles of the scapulohumeral shaft are developed (fact highlighted in maintenaning traction test, where $r=0.75$ ).

The best values of the correlation index were obtained in the tests involving the flexor muscles of the arms and back (continuing hanging after tractions, $r=0.75$; lifting the torso from lying face down, $r=0.79$ ), as well as and the flexor muscles of the torso (hanging legs raises $r=0.73$ ). Therefore, we could say that the repetition of technical procedures in martial arts influences to a greater extent the flexor muscles of the upper limbs and torso, the lumbar muscles, followed by the extensor muscles of the lower limbs.

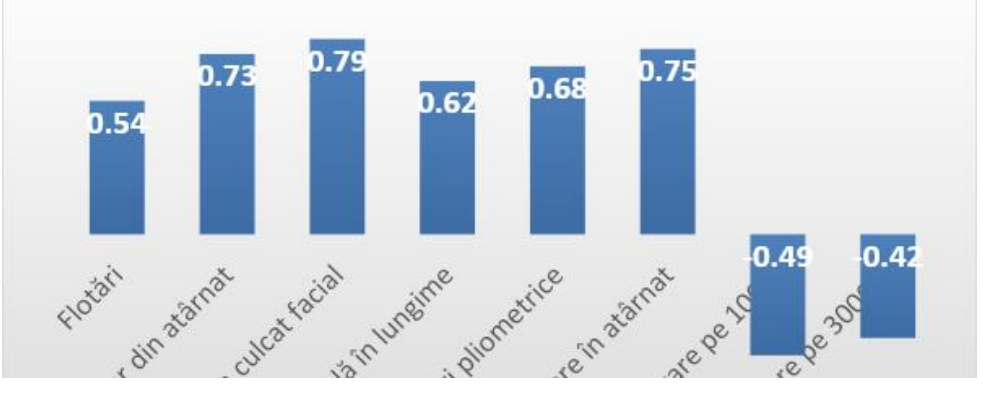

Fig. 4. Correlation of progress in technical procedures with general physical training tests

However, calculated on the average values, both those of progress in technical procedures and general physical training, the correlation coefficient has a value we expected: $r=6275$, which validates the natural hypothesis, ie: the progress made in the 
technical procedures are closely related to the improvement of physical condition, quantified in the progress made in general physical training.

Regarding the correlation between the technical tests and the tests of special physical training, the values obtained are between $r=$ 0.59 at the upper limit of the reasonable correlation and high correlation, up to the very high correlation limit, $r=0.87$ (Figure 5).

The level of correlation for the "Shuttle" test $(r=0.59)$ is explained by the low level of "speed" motor quality education (which is basic in this test) at the specific age of the research subjects.

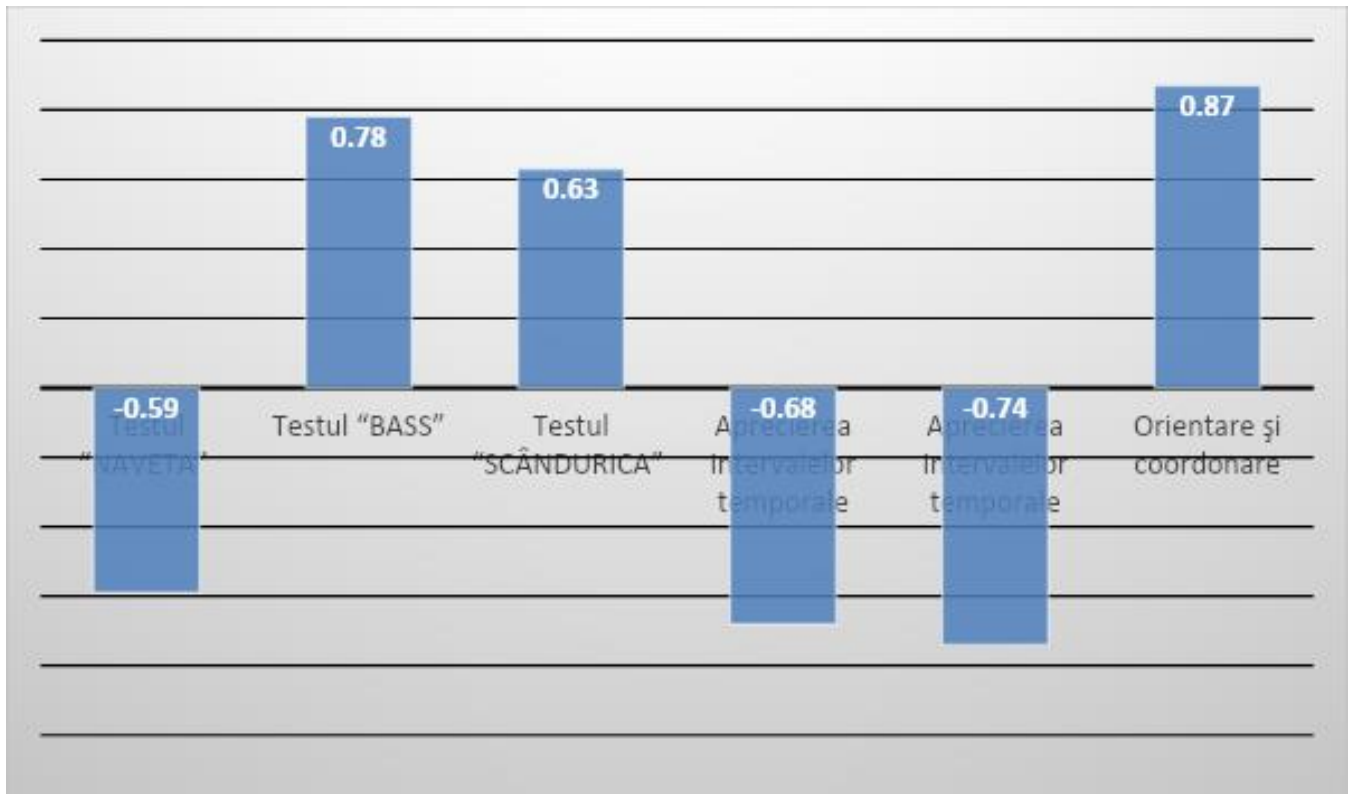

Fig.5. Correlation between technical procedures and special physical training tests

The highest correlation values were recorded in the "Bass" test and in the orientation and coordination test $(r=0.78$ and $\mathrm{r}=0.87$, respectively). These values were a natural consequence of the repetition of a large number of movements simultaneously, in different planes and directions, specific to martial arts techniques. These tests call in particular on spatio-temporal coordination, orientation and observational spirit. The abilities described above are very frequently used in individual, direct confrontations, specific to hand-to-hand combat and, to a lesser extent, in the demonstrative execution of techniques (a form of repetition that greatly stimulates the imagination).

Consequently, in order to ascertain the influence of martial arts means (technical procedures) on all indicators of general and special physical training, a general correlation matrix was made (Table 1), identifying the technical procedure that had the highest correlation based on the average of the values obtained for each registered parameter (Figure 6). Thus, a high correlation between the technical procedures and the other indicators is recorded by the technique of throwing over the hip - Koshi Nage $(r=0.689)$ and the repeated kick - Mawashi Geri $(r=0.68)$. These values are explained by the fact that the two techniques use at least two motor qualities and have a high application value. The execution of the "throwing over the hip" technique (Koshi Nage) requires strength in the arms, back and legs, but also coordination and orientation in space. 
Repeated Kick (Mawashi Geri) requires speed of execution, balance, coordination and strength in the muscles of the supporting leg. At the same time, both methods have a great applicability in hand-to-hand combat, both as a form of attack and as a form of self-defense.

The highest value of the mean correlation was recorded when fixing the forearm to the ground (Ude Osae), $r=0.614$, namely a high correlation. This procedure calls for a very good individual coordination, but also for coordination between the two performers.

Therefore, the aikido procedures were highly correlated in the coordination and orientation tests, the judo tests in the general physical training and coordination tests, and the karate ones in speed, orientation and balance.

Table 1. General correlation matrix of monitored indicators

\begin{tabular}{|c|c|c|c|c|c|c|c|c|c|c|c|c|c|c|c|c|c|c|c|c|c|c|c|}
\hline \multirow{2}{*}{$\begin{array}{l}\text { No. } \\
\text { crit. }\end{array}$} & \multirow{2}{*}{$\begin{array}{l}\text { Correlation } \\
\text { criteria }\end{array}$} & \multicolumn{22}{|c|}{ Correlation coefficients „r” } \\
\hline & & 1 & 2 & 3 & 4 & 5 & 6 & 7 & 8 & 9 & 10 & 11 & 12 & 13 & 14 & 15 & 16 & 17 & 18 & 19 & 20 & 21 & 22 \\
\hline 1 & $\begin{array}{c}\text { Running } \\
100 \mathrm{~m}\end{array}$ & $\mathbf{x}$ & 0.45 & 0.30 & 0.32 & 0.36 & 0,42 & 0.44 & 0.17 & 0.68 & 0.15 & 0.12 & 0.10 & 0.09 & 0.15 & 0.48 & 0.51 & 0.60 & 0.59 & 0.51 & 0.53 & 0.52 & 0.70 \\
\hline 2 & $\begin{array}{l}\text { Running } \\
3000 \mathrm{~m}\end{array}$ & 0.25 & $\mathbf{x}$ & 0.18 & 0.15 & 0.18 & 0.22 & 0.23 & 0.09 & 0.32 & 0.08 & 0.08 & 0.14 & 0.15 & 0.18 & 0.42 & 0.42 & 0.57 & 0.54 & 0.49 & 0.51 & 0.55 & 0.58 \\
\hline 3 & Plyo push-ups & 0.30 & 0.18 & $\mathbf{x}$ & 0.39 & 0.42 & 0.31 & 0.17 & 0.31 & 0.36 & 0.16 & 0.11 & 10.08 & 0.10 & 0.14 & 0.53 & 0.62 & 0.58 & 0.62 & 0.63 & 0.64 & 0.59 & 0.54 \\
\hline 4 & $\begin{array}{c}\text { Hanging legs } \\
\text { raises }\end{array}$ & 0.32 & 0.15 & 0.39 & $\mathbf{x}$ & 0.36 & 0.30 & 0.26 & 0.52 & 0.21 & 0.14 & 0.18 & 0.14 & 0.12 & 0.17 & 0.68 & 0.56 & 0.64 & 0.67 & 0.72 & 0.74 & 0,71 & 10.70 \\
\hline 5 & $\begin{array}{l}\text { Lifting the torso } \\
\text { at the gymnastic } \\
\text { box }\end{array}$ & 0.36 & 0.18 & 0.42 & 0.36 & $\mathbf{x}$ & 0.34 & 0.28 & 0.14 & 0.29 & 0.07 & 0.21 & 0.17 & 0.15 & 50,20 & 0.71 & 0.61 & $0.67 \mid$ & 0.71 & $0.81 \mid$ & $|0.79|$ & 0.75 & 0.73 \\
\hline 6 & \begin{tabular}{|c|}
$\begin{array}{c}\text { Double long } \\
\text { jump }\end{array}$ \\
\end{tabular} & 0.42 & 0.22 & 0.31 & 0.30 & 0.34 & $\mathbf{x}$ & 0.81 & 0.08 & 0.41 & 0.15 & 0.26 & 0.22 & 0.18 & 0.17 & 0.62 & 0.57 & 0.61 & $0.68 \mid$ & 0.70 & 0.68 & 0.70 & 0.75 \\
\hline 7 & Pliometric jumps & 0,44 & 0.23 & 0.17 & 0.26 & 0.28 & 0.81 & $\mathbf{x}$ & 0.12 & 0.43 & 0.25 & 0.29 & 0.24 & 0.22 & 0.26 & 0.61 & 0.59 & 0.63 & 0.65 & 0.73 & 0.67 & 0.65 & 0.72 \\
\hline 8 & $\begin{array}{c}\text { Continuing } \\
\text { hanging after } 8 \\
\text { traction }\end{array}$ & 0.17 & 0.09 & 0.31 & 0.52 & 0.14 & 0.08 & 0.12 & $\mathbf{x}$ & 0.24 & 0.26 & 0.15 & 0.07 & 0.10 & 0.22 & 0.54 & 0.55 & 0.68 & 0.72 & 0.79 & 0.75 & 0.73 & 0,52 \\
\hline 9 & \begin{tabular}{c|} 
Shuttle \\
\end{tabular} & 0.68 & 0.32 & 0.36 & 0.21 & 0.29 & 0.41 & 0.43 & 0.24 & $\mathbf{x}$ & 0.21 & 0.18 & 0.13 & 0.16 & \begin{tabular}{|c|c|} 
\\
\end{tabular} & 0.56 & 0.62 & 0.52 & 0.52 & 0.75 & 0.77 & 0.72 & 0.77 \\
\hline 10 & Bass & 0.15 & 0.08 & 0.16 & 0.14 & 0.07 & 0.15 & 0.25 & 0.26 & 0.21 & $\mathbf{x}$ & 0.32 & 0.32 & 0.28 & 30.46 & 0.55 & 0.71 & 0.70 & 0.69 & 0.68 & 0.65 & 0.60 & 0.63 \\
\hline 11 & Scandurica & 0.12 & 0.08 & 0.11 & 0.18 & 0.21 & 0.26 & 0.29 & 0.15 & 0.18 & 0.32 & $\mathbf{x}$ & 0.28 & 0.32 & 0.41 & 0.72 & 0.78 & 0.73 & 0.73 & 0.62 & 0.60 & 0.58 & 0.79 \\
\hline 12 & $\begin{array}{l}\text { Appreciation of } \\
\text { ime intervals } 3\end{array}$ & 0.10 & 0.14 & 0.08 & 0.14 & 0.17 & 0.22 & 0.24 & 0.07 & 0.13 & 0.32 & 0.28 & $\mathbf{x}$ & 0.70 & 0.39 & 0.58 & 0,75 & 0.69 & 0.59 & 0.65 & 0.66 & 0.63 & 0.69 \\
\hline 13 & $\begin{array}{l}\text { Appreciation of } \\
\text { ime intervals } 5\end{array}$ & 0.09 & 0.15 & 0.10 & 0.12 & 0.15 & 0.18 & 0.22 & 0.10 & 016 & 0.28 & 0.32 & 0.70 & $\mathbf{x}$ & 0.42 & 0.61 & 0.57 & 0.67 & 0.60 & 0.73 & 0.71 & 0.68 & 0.67 \\
\hline 14 & $\begin{array}{c}\text { Orientation and } \\
\text { coordination }\end{array}$ & 0.15 & 0.18 & 0.14 & 0.17 & 0.20 & 0.17 & 0.26 & 0.22 & 0.42 & 0.46 & 0.41 & 0.39 & 0.42 & $\mathbf{x}$ & 0.60 & 0.59 & 0.77 & 0.70 & 0.70 & 0,75 & 0.70 & 0.70 \\
\hline 15 & Ude-osae & 0.48 & 0.42 & 0.53 & 0.68 & 0.71 & 0.62 & 0.61 & 0.54 & 0.56 & 0.55 & 0.72 & 0.58 & 0.61 & 0.60 & $\mathbf{x}$ & 0.62 & 0.73 & 0.77 & 0.68 & 0.62 & 0.60 & 0.68 \\
\hline 16 & $\begin{array}{c}\text { Kote } \\
\text { mawashi }\end{array}$ & 0.51 & 0.42 & 0.62 & 0.56 & 0.61 & 0.57 & 0.59 & 0.55 & 0.62 & 0.71 & 0.78 & 30.75 & 0.57 & 0.59 & 0.62 & $\mathbf{x}$ & 0.72 & 0.82 & 0.65 & 0.59 & 0.55 & 0.86 \\
\hline 17 & Kote Gaeshi & 0.60 & 0.57 & 0.58 & 0.64 & 0.67 & 0.61 & 0.63 & 0,68 & 0.52 & 0.70 & 0.73 & 0.69 & 0.67 & 0.77 & 0.73 & 0.72 & $\mathbf{x}$ & 0.74 & 0.81 & 0.61 & 0.59 & 0.71 \\
\hline 18 & Kote Hineri & 0.59 & 0,54 & 0.62 & 0.67 & 0.71 & 0.68 & 0.65 & 0.72 & 0.52 & 0.69 & 0.73 & 0.59 & 0.60 & 0.70 & 0.77 & 0.82 & 0.74 & $\mathbf{x}$ & 0.68 & 0.57 & 0.60 & 0.68 \\
\hline 19 & Koshi nage & 0.51 & 0.49 & 0.63 & 0.72 & 0.81 & 0.70 & 0.73 & 0.79 & 0.75 & 0.68 & 0.62 & 0.65 & 0,73 & 30.70 & 0.68 & 065 & 0.81 & 0.68 & $\mathbf{x}$ & 0.80 & 0.71 & 0.60 \\
\hline 20 & Ippon seio-nage & 0.53 & 0.51 & 0.64 & 0.74 & 079 & 068 & 0.67 & 0.75 & 0.77 & 0.65 & 0.60 & 0.66 & 0.71 & 0.75 & 0.62 & 0.59 & 0.61 & 0.57 & 0.80 & $\mathbf{x}$ & 0.69 & 0.66 \\
\hline 21 & O-soto-gari & 0.52 & 0.55 & 0.59 & 0.71 & 0.75 & 0.70 & 0.65 & 0.73 & 0.72 & 0.60 & 0.58 & 0.63 & 0.68 & 0.70 & 0.60 & 0.55 & \begin{tabular}{|l|}
0.59 \\
\end{tabular} & 0.60 & 0.71 & 0.69 & $\mathbf{x}$ & 0.62 \\
\hline 22 & $\begin{array}{c}\text { Mawashi } \\
\text { Geri }\end{array}$ & 0.70 & 0.58 & 0.54 & 0.70 & 0.73 & 0.75 & 0.72 & 0.52 & 0.77 & 0.63 & 0.79 & 0.69 & 90.67 & 0.70 & 0.68 & 0.86 & 0.71 & 0.68 & 0.60 & 0.66 & 0.62 & $\mathbf{x}$ \\
\hline
\end{tabular}

Given the specifics of the structure of the academic year (interrupted teaching periods of holidays during religious holidays and holidays between semesters, as well as session periods for examination), we can say that the subjects made considerable progress in all the tests of the study as following the application of the experimental program consisting of martial arts means. 


\section{Conclusions}

Following the tests and analysis of the results obtained, we can formulate the following conclusions:

1. Both groups made progress in both general and special physical fitness tests:

- the experimental group made more progress, different from one test to another, when running $100 \mathrm{~m}$, running $3000 \mathrm{~m}$, hanging legs raises, lifting the torso from lying face down, double long jump and continuing hanging after 8 traction, where the difference between the two sizes is significant at the threshold of $0.1 \%$ ( $\mathrm{P}<0.001)$; and in plyo push-ups and plyometric jumps the significance threshold is $1 \%(\mathrm{P}<0.01)$;

- the special physical training indices highlight the influence of martial arts specific skills in the formation and development of balance skills, in the "Bass" and "Orientation and coordination" test, the difference being significant, $\mathrm{P}<0.001$, and in the other tests the significance threshold is $\mathrm{P}<0.01$;

2. The experimental group registers a qualitative leap in the execution of technical procedures, especially in the second part of the academic year, because consolidation and improvement topics have been scheduled $(\mathrm{P}<0.01)$. In this context, we can also highlight the fact that the technical procedures in judo can be learned faster than those in karate and aikido due to their applicability;

3. The correlative analysis of the results of the experimental group revealed the existence of a very high correlation $(0.6 \leq \mathrm{r} \geq 0.8)$ between the results recorded in the special physical training tests and the technical procedures, which demonstrate a close link between the development of specific motor qualities and the accuracy of the execution of the procedures specific to the martial arts practiced;

4. The matrix of the correlation between the level of progression of the technical processes and the other indicators highlights the fact that the judo processes register a high correlation $(0.6 \leq r \geq 0.8)$ with the indicators of strength and speed tests, and the skills in karate and aikido have a similar correlation with the indicators of coordination, orientation, balance tests.

\section{References :}

1. Băițan G-Fl (2019). Pregătirea fizică a militarilor din Armata României în contextul integrării în NATO. București: Editura Universităţii Naţionale de Apărare „Carol I”. 307 p.

2. Ene-Voiculescu V. (2007). Tehnica și metodica predării în probele aplicativ-militare de vară și de iarnă. Constanța: Editura Academiei Navale „Mircea cel Bătrân”.160 p.

3. Ene-Voiculescu V. (2011). Managementul educației fizice în forțele navale. Constanța: Editura Academiei Navale „Mircea cel Bătrân”. 203 p.

4. Galan D. (2007). Autoapărarea pentru studenți - anul II de studiu. Cluj-Napoca: Editura RISOPRINT. $281 \mathrm{p}$.

5. Oneț I. (2006). Pregătirea fizică profesional aplicativă a studenților de la facultățile de nave în cadrul lecțiilor de educație fizică. Teză de doctor în științele pedagogice. Chișinău, 145 p.

6. Stănciulescu R. (2007). Studiu privind optimizarea pregătirii fizice a ofiţerilor studenţi, prin mijloacele specifice sporturilor de luptă, în vederea compatibilizării cu standardele impuse pentru integrarea României în N.A.T.O. Teză de doctorat. București: A.N.E.F.S.

7. Suzuki Sh. (2012). Mintea Zen, mintea începătorului. București: Editura Herald. 203 p.

8. Doctrina Forțelor Terestre (2004). București.

9. Legea educației naționale nr.1/ 2011. Publicat: Monitorul Oficial al României nr.18 din 10.01.2011, Partea I.

10. Regulamentul Educației Fizice Militare. Centrul Tehnic Editorial al Armatei, Statul Major General, București, 2013.

11. Regulamentul Instrucţiei de Paraşutare - Pşt.9, 1984. 